\title{
Fan-surface dynamics and biogenic calcrete development: Interactions during ultimate phases of fan evolution in the semiarid SE Spain (Murcia)
}

\author{
Ana M. Alonso-Zarza ${ }^{\mathrm{a}, *}$, Pablo G. Silva ${ }^{\mathrm{b}}$, José L. Goy ${ }^{\mathrm{c}}$, Cari Zazo ${ }^{\mathrm{d}}$ \\ ${ }^{a}$ Departamento de Petrología y Geoquímica, Facultad Ciencias Geológicas, Universidad Complutense de Madrid, 28040 Madrid, Spain

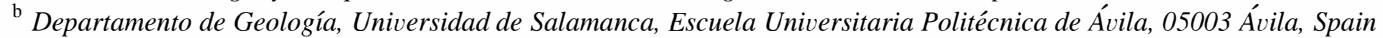

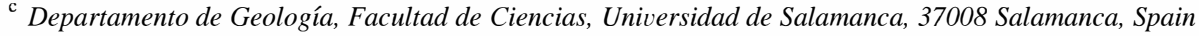

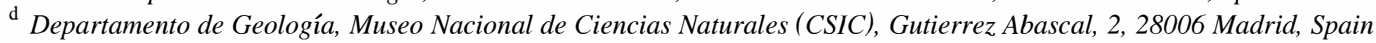

\begin{abstract}
Pleistocene alluvial fan surfaces of the Campo de Cartagena-Mar Menor Basin (Murcia, SE Spain) are capped by thick mature calcretes. Calcrete profiles consist mainly of six different horizons: prismatic, chalky, nodular, massive, laminar and coated-gravels. Petrographic study of the calcretes has shown the occurrence of features such as alveolar septal structures, calcified filaments, coated grains, spherulites, calcified root cells and calcispheres that indicate the biogenic origin of the calcretes, mainly induced by plant root related microbial activity. The calcretes studied were formed initially in the soil and represented the K horizon. Development of the calcrete profiles took place in six main stages and was driven by multiple phases of soil formation, erosion and reworking. The relationships between these processes caused the formation of different calcrete profiles in proximal and distal fan areas. In the distal areas, which are controlled by limited distal fan aggradation, episodic sediment input, buried previously developed calcretes and generated new space for calcrete growth by plants growing in the overlying unconsolidated materials. This allowed the renewal of calcrete formation and it led to the development of complex composite profiles which are thicker than in proximal areas, where surface stabilisation and/or dissection enabled calcrete reworking and brecciation. These processes of erosion, sedimentation, reworking and renewed calcrete formation initiated by vegetation were repeated through time. They explain the complex macro- and microstructures of these calcretes and indicate that calcrete development, even reaching mature stages, can start before the fan surface is completely abandoned, but it requires episodic sedimentation. Eventually, distal fan aggradation and continuous calcrete development throughout the entire fan surface, led to the ultimate fan surface induration, controlling subsequent landscape evolution. So, fan surface calcretes cannot be envisaged as simple top-surface carbonate accumulations, but as complex feedback systems in which pedogenic, biogenic and sedimentary processes interact in response to the evolving fan-surface dynamics during the terminal phases of fan development in semiarid environments. (C) 1998 Elsevier Science B.V. All rights reserved.
\end{abstract}

Keywords: calcretes; fan surface dynamics; plant-root activity; Quaternary; SE Spain

\footnotetext{
* Corresponding author. Tel.: +34-1-3944915; Fax: +34-1-5-44-25-35; E-mail: alonsoza@eucmax.sim.ucm.es
} 


\section{Introduction}

During the last 30 years, the study of calcretes has become a major topic for sedimentologists, geomorphologists and soil-scientists. The increasing interest is due to the fact that calcretes are formed within soil profiles and it requires specific, geomorphological and/or sedimentary settings. Hence, their occurrence and characteristics provide a useful tool for the interpretation of the sedimentary environment and paleogeography of the area where they were formed. Moreover, calcrete development itself is not well understood, and the variety of proposed genetic models arise from the debate between the specific role of pedogenic, biologic and synsedimentary processes in their formation.

Calcrete development is a characteristic feature on Quatemary fan surfaces in modern semiarid environments, indicating very limited sedimentation and/or surface stabilisation (Goudie, 1973). Calcretes have a strong impact on fan-surface geomorphology, controlling the degree of surface induration, planation, and future preservation (Latman, 1973). The degree of calcrete development can control the extent and location of the sedimentary and erosive processes on fan surfaces. Indurated surfaces can prevent lateral channel erosion, favouring linear incision in the more friable underlying chalky and nodular horizons, but may also reduce infiltration rates, thereby accelerating runoff and favouring the development of karstic micro-forms (Goudie, 1973; Latman, 1973). Calcrete formation on these fan surfaces seems to be the result of complex geomorphic, biogenic and pedogenic processes, in which plant roots and associated microorganisms play an important role (Montenat, 1981; Vogt, 1984; Verrecchia, 1987; Wright, 1991; Sancho and Meléndez, 1992; Alonso-Zarza et al., 1998).

Calcrete crusts occur widely in semiarid SE Spain, capping Pleistocene fan surfaces, being one of the more extended and distinctive 'facies' of these deposits (Harvey, 1984, 1990). Some of the classical models of calcrete development and related processes are based on studies from this zone (Dumas, 1977; Montenat, 1981). In this paper we describe different calcrete profiles developed on middle-late Pleistocene fan surfaces from SE Spain (Campo de Cartagena, Murcia). The results obtained in this study came from an integrated petrological and geomorphological analysis of calcrete profiles and fan surfaces. In doing so, we intend to show that calcrete formation and fan surface dynamics are so closely linked, that they behave as a whole feedback system.

\section{Geological and geomorphological setting}

The study area is located in the Eastern Betic Cordillera in the inland sector of the Campo de Cartagena (Fig. 1). In this zone, two of the most important stike-slip Quaternary basins of the region meet, the Guadalentin Depression and the Mar Menor Basin (Silva et al., 1993). This zone constitutes a narrow tectonic corridor bounded by the Sierra de Carrascoy to the North, and to the South by the Sierra del Algarrobo and ancient late Neogene reliefs on deformed marine sediments. Along this corridor, an ancient Plio-Pleistocene fluvial system, coming from the Guadalentin Depression, flowed towards the Mediterranean sea (Mar Menor), connecting the two basins and leaving up to $150 \mathrm{~m}$ of fluvial sediments (Silva, 1994). Subsequent middle Pleistocene tectonics, broke up the ancient fluvial system through the generation of a set of N-S trending normal faults, which disconnected the basins and triggered the development of a partly enclosed portion in the study area. This led to the development of transverse alluvial fan systems (Silva et al., 1996) fed by marginal reliefs.

The most recent drainage development in this area has led to partial relief inversion in the southern part. The Holocene headward erosion of the drainage network of the Mazarrón Basin, directly connected to the Mediterranean sea, eroded part of the southem late Neogene reliefs in which some of the study fans had their headwaters (Silva et al., 1996). Also, several stream captures are evident in the ancient fan headwaters, located within the Sierra del Algarrobo, by drainage systems flowing to the Mediterranean (Fig. 2). These facts, suggest that sediment supply to the study fans was disrupted by the capture of their former drainage basins, leading to a premature abandomnent of the fan surfaces during the late Pleistocene. The present geomorphology of this southem zone is dominated by a large escarpment (10-19 m high, El Saladillo Scarp), which beheads most of the 


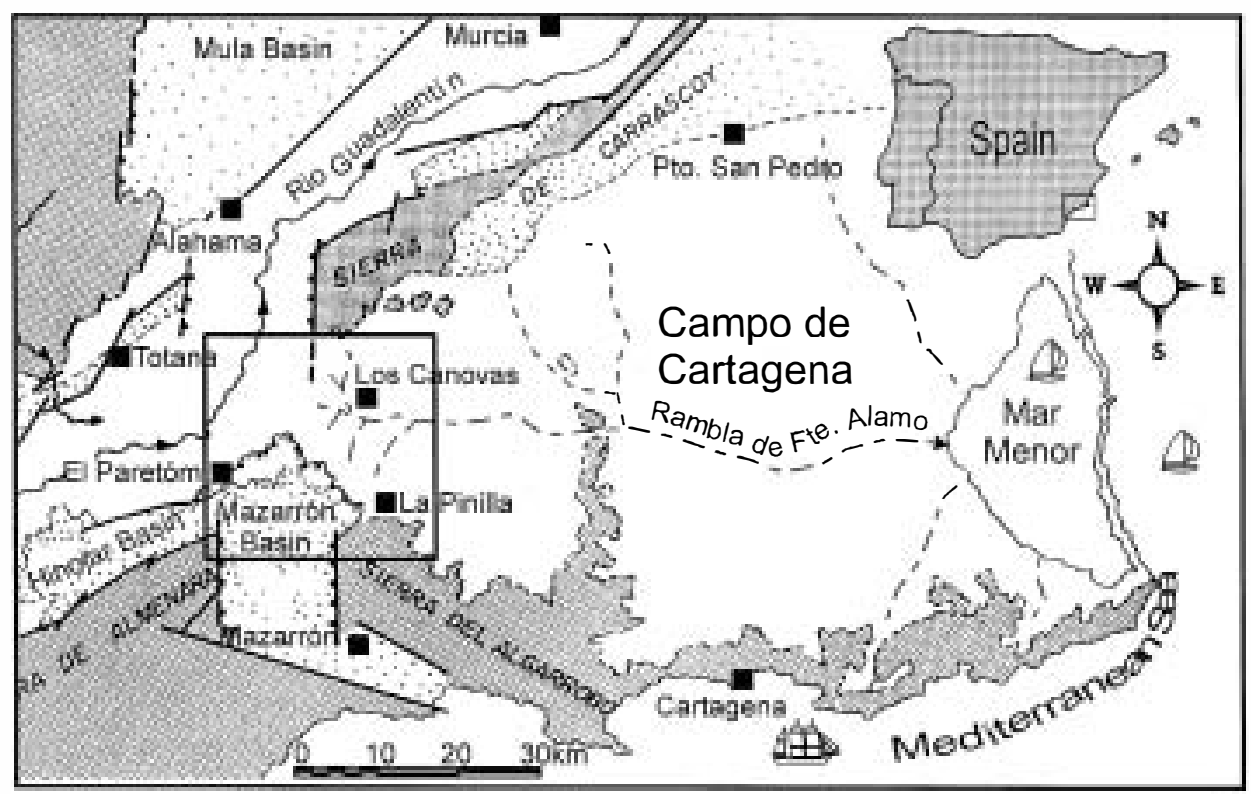

Fig. 1. Location of the study area within the Eastern Betic Cordillera (SE Spain). Shaded zones are major reliefs, pointed zones are late Neogene basins and plain zones, represent Quaternary sediments. Major geological structures are also shown.

Pleistocene fan surfaces, and forms a tableland landscape, controlled by the occurrence of indurated calcrete crusts on the abandoned fan surfaces (Fig. 2). Geomorphological mapping, indicates that the former proximal and distal fan segments were integrated as one indurated geomorphic level linked to calcrete development. Apart from the strong erosive processes beheading fan surfaces along the southern El Saladillo Scarp, little local denudation has occurred on the rest of the ancient fan surfaces since they were prematurely abandoned. Fan surfaces are being dissected today by rills and gullies, which rise on this surface and are tributaries of old, presently incised, interfan channels. The latter delineate of the ancient individual fan geometry, and most of them are also beheaded at the scarp. The incised interfan channels are connected to the Rambla Fuente Alamo, an E-W channel, which flows towards the Mar Menor and constitutes the axial drainage of the Campo de Cartagena.

\subsection{Bedrock and fan geology}

The study fans issued from the Sierra del Algarrobo and former late Neogene reliefs, onto the down- faulted and tilted Plio-Pleistocene fluvial deposits that infill the tectonic corridor, but in proximal areas they can rest on older marly marine Neogene deposits (Fig. 2). Source area geology, varies from the high-grade metamorphic rocks, marbles and lowgrade carbonate metamorphic rocks of the Sierra del Algarrobo to the marine marls and calcarenites of the former late Neogene reliefs located to the west.

Fan deposits constitute thin alluvial veneers which thicken downfan (South to North) from 3 to 5-6 m, cut into previous mature red soils, with prismatic $\mathrm{Bt}$ argilic horizons (7.5YR 5/6) to 1-2 m thick, developed on the former fluvial sediments. They can be grouped into two, those in the proximal fan areas, close to the El Saladillo Scarp, characterised by fining upwards, clast-supported, subangular gravels with interbedded silty layers, inset by flat gravel channels with $\mathrm{Gm} / \mathrm{Gp}$ facies (distributary channels), and those in the distal fan areas, comprising reddish silty-clayey structureless deposits, with thin interbedded fine sandy bodies of pseudo-tabular and/or channel-shaped geometry with basal gravel lags. The more distal deposits record the occurrence of, at least, two red paleosols with discrete Bt prismatic horizons (5YR 4/6). In contrast, the proximal gravel 


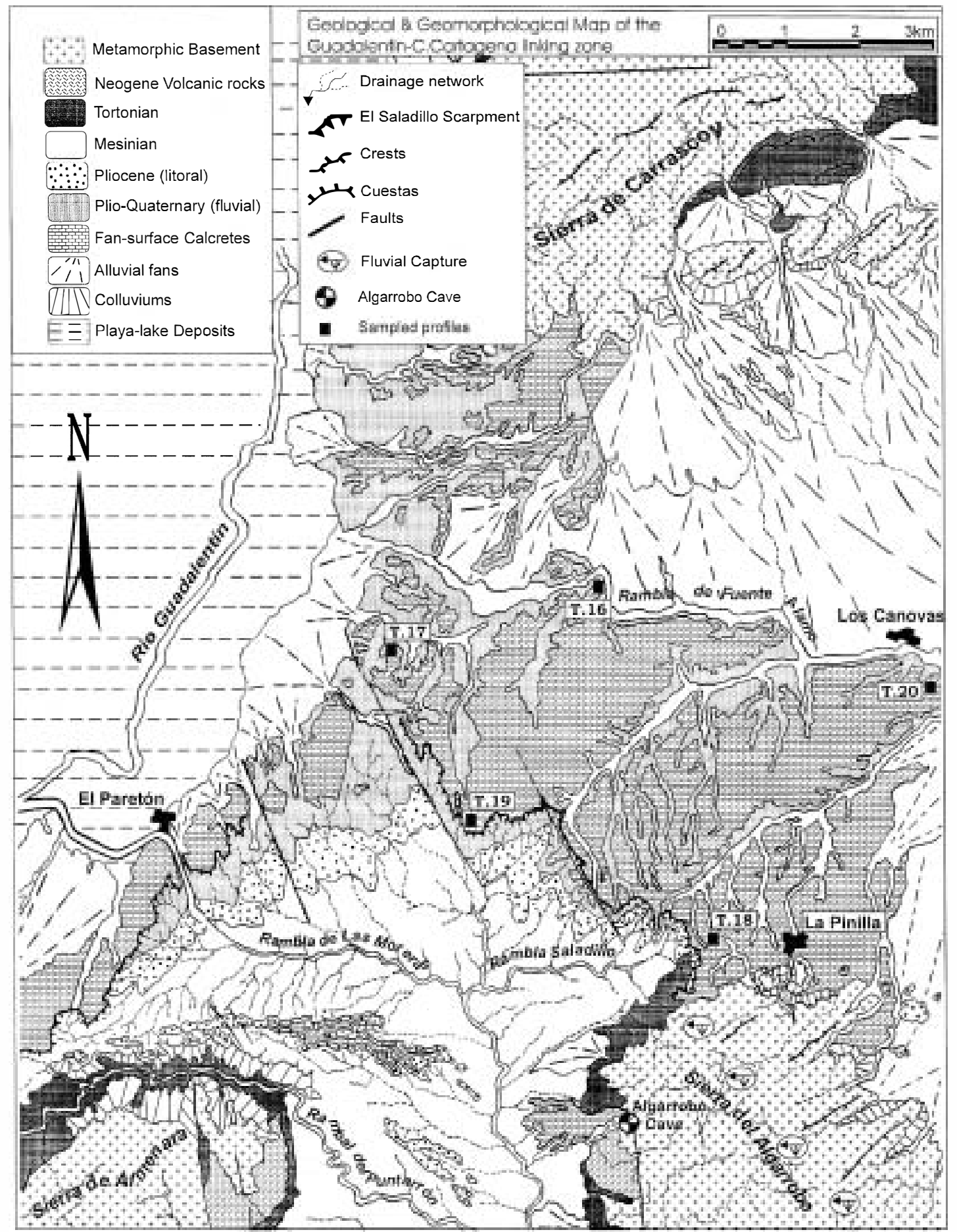

Fig. 2. Detailed map of the Gudalentín Depression-Campo de Cartagena Basin linking zone showing the main geological and geomorphological units and the location of the studied calcrete profiles. 
supports a single, but more developed red soil, with a thick Btc horizon (7.5YR 4/8), although weakly developed brown paleosols are common within channel fillings. Taking into account pedostratigraphic and dynamic models for alluvial fans (Harvey, 1984; Wright and Alonso-Zarza, 1990), the recorded sedimentary facies and pedogenic features indicate that the last stages of fan development were probably controlled by proximal trenching and distal aggradation. Eventually, inset channels located in proximal areas were filled, promoting the occurrence of thin, fine-sediment sheet floods throughout the entire fan surface on which calcrete development took place, contributing to the ultimate homogenisation of fan surfaces.
Fan surfaces are currently inactive, supporting massive indurated calcrete crusts, $2-3 \mathrm{~m}$ thick, over the entire fan surfaces. In some cases carbonate accumulation linked to calcrete development can reach $5 \mathrm{~m}$ deep, affecting the former fluvial red paleosols (Fig. 3A and B). Calcretes can display a different number of calcic horizons, characterised by the occurrence of surface laminar horizons, similar to the stage VI of Machette (1985). Three broad age-related types of calcrete crust have been traditionally considered in southeast Spain (Dumas, 1977; Harvey, 1984 and Silva et al., 1992): Weak calcretes (stage II) of late Pleistocene (Würm) age; Mature calcretes (stages II-IV) of pre-Würm age; and Massive calcretes (Stages V-VI) of early-middle Pleis-
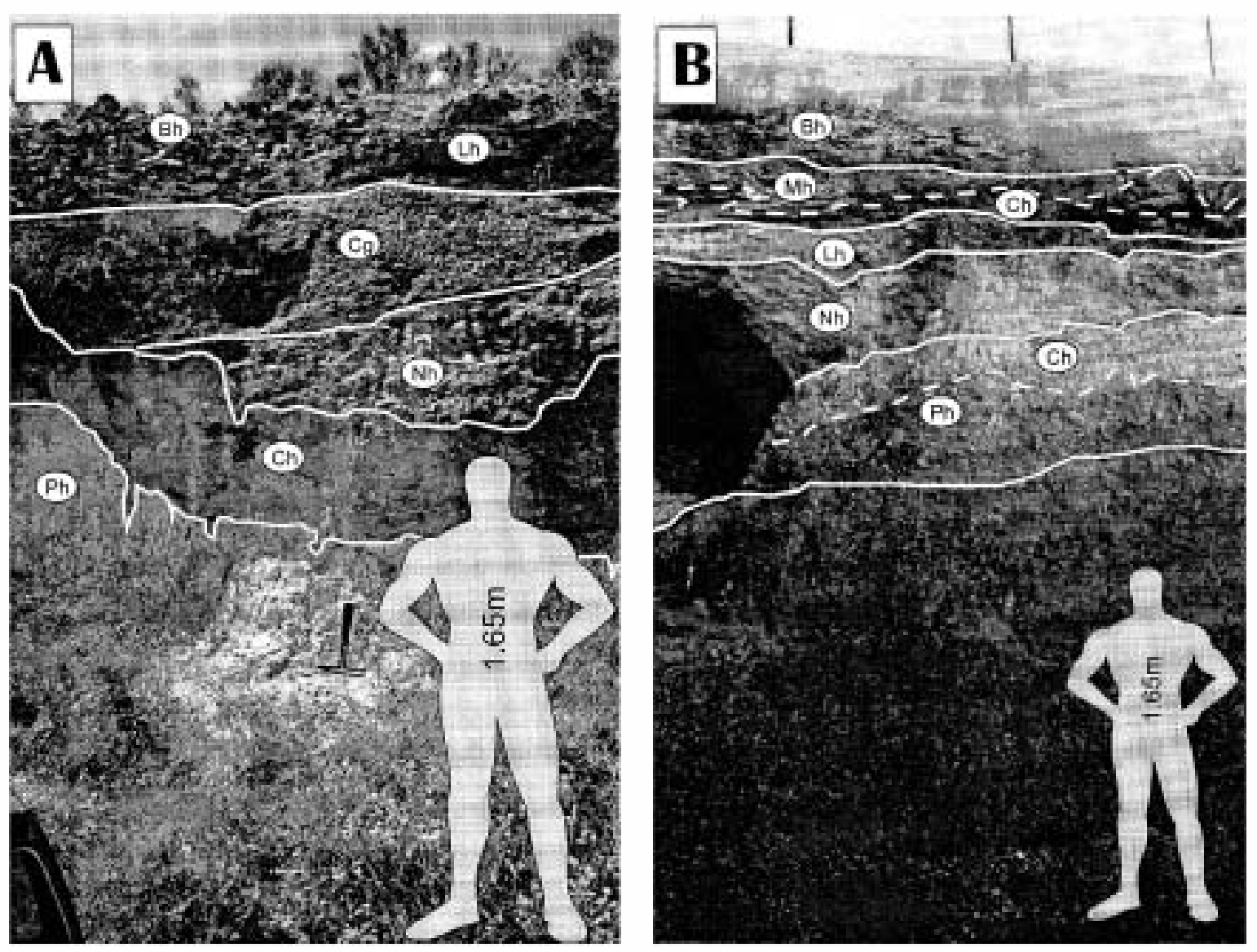

Fig. 3. (A) Calcrete profile in the proximal area. Railway section (T18 in Fig. 2). (B) Calcrete profile in the distal area (T20 in Fig. 2 ). Note that the profile is thicker than A. For calcrete horizon codes, see Fig. 4. 
tocene age. On the basis of the calcrete development stages, these fan deposits have been commonly assigned to the Plio-Pleistocene Sucina Formation of Montenat (1981), but more recent studies on fan sequences in south-east Spain indicate that this kind of massive calcrete is not a good quality age-indicator, as suggested by Latman (1973), and probably only indicated a pre-Würm age (Harvey, 1990; Silva et al., 1992). In addition, paleomagnetic studies in alluvial deposits of the eastemmost sector of the Campo de Cartagena Basin, indicated that similar fan-surface calcretes post-date the BruhnesMatuyama reversal, suggesting a broad middle Pleistocene age for these carbonate accumulations (Somoza et al., 1989). Moreover, the relationships of similar massive calcretes with Tyrrhenian deposits in the neighbouring Elche Basin, indicate that their development could even be younger, of middle-late Pleistocene age ca. 250 ky ago (Goy et al., 1990).

\subsection{Climate and vegetation}

The present climate is semiarid, with total precipitation ranging between ca. $350 \mathrm{~mm} / \mathrm{yr}$ to ca. 250 $\mathrm{mm} / \mathrm{yr}$, and with most precipitation concentrated in short-episodic stormy events in autumn and spring, the so called 'Cold-Drop Events' (López Gómez and López Gómez, 1987). Pleistocene climates in the Betic Cordillera, recorded in high-altitude palynological surveys, also appear to have been dry during the cold phases, with insufficient moisture to support extensive tree covers (Pons and Reille, 1988). The nearby palynological records, from cave-fillings of the Sierra del Algarrobo, indicate that the important Quatemary climatic fluctuations recorded in Europe were not relevant to the low-altitude Mediterranean zone. No substantial vegetation changes have been recorded in the last 250,000 years, which have been dominating by a steppe-type cover of xeroesclerofile bushes characterised by the occurrence of species of Artemisia and Chenopodiaceae (Munuera and Carrión, 1991). These species are similar to the ones sparsely distributed on the present fan surface relics.

Under the present conditions the fan surface calcretes are unstable. They show variable stages of degradation by plant root disruption and weathering, resulting in the occurrence of unconsolidated caliche rubble (sense of Latman, 1973), constituted by angular fragments of laminar and brecciated calcrete embedded in a reddish-brown clay matrix. Both, the clast plant-root relationships and the angularity of the clasts, seem to indicate that mechanical rather than chemical processes are the cause of the present calcrete degradation.

\section{Techniques and methods}

Five selected calcrete profiles were studied. Two of them developed on proximal areas of alluvial fans and the others corresponding to calcrete development on distal fan deposits (Figs. 4 and 5). For each profile, one sample was obtained from every distinctive horizon, and about 65 were studied under the transmitted light microscope. Scanning electron microscopy was carried out on a JEOL 6.400 working on $20 \mathrm{kV}$, and fracture surfaces covered with gold were used. The mineralogy of the samples was determined using a Philips XRD system operating at 40 $\mathrm{kV}$ and $30 \mathrm{~mA}$ with a Monochrome $\mathrm{CuK}_{\alpha}$ radiation. Clay mineralogy was determined after reating the powdered sample with $5 \% \mathrm{HCl}$ for $24 \mathrm{~h}$.

\section{Calcrete profiles}

The calcrete profiles of the study area were formed from well differentiated horizons of carbonate accumulation on a macro and microscale. In this section, the macro and micromorphology and sequential arrangement of the six recognised horizons on both proximal and distal areas of fan surfaces are described (Figs. 4 and 5). Soil horizons strongly impregnated by carbonate are termed as $\mathrm{K}$ horizons, according to the terminology of Gile et al. (1965). If the horizons are formed from root activity, Wright et al. (1995), proposed the use of the suffix 'rh'. In the case study, the whole calcrete profiles correspond to a $\mathrm{K}$ horizon, that contains several different morphological horizons, which do not occur in the same part of the profile, so we name them according to the terminology of Esteban and Klappa (1983) on the basis of their most prominent feature. They mostly respond to the classic prismatic, chalky, nodular, 

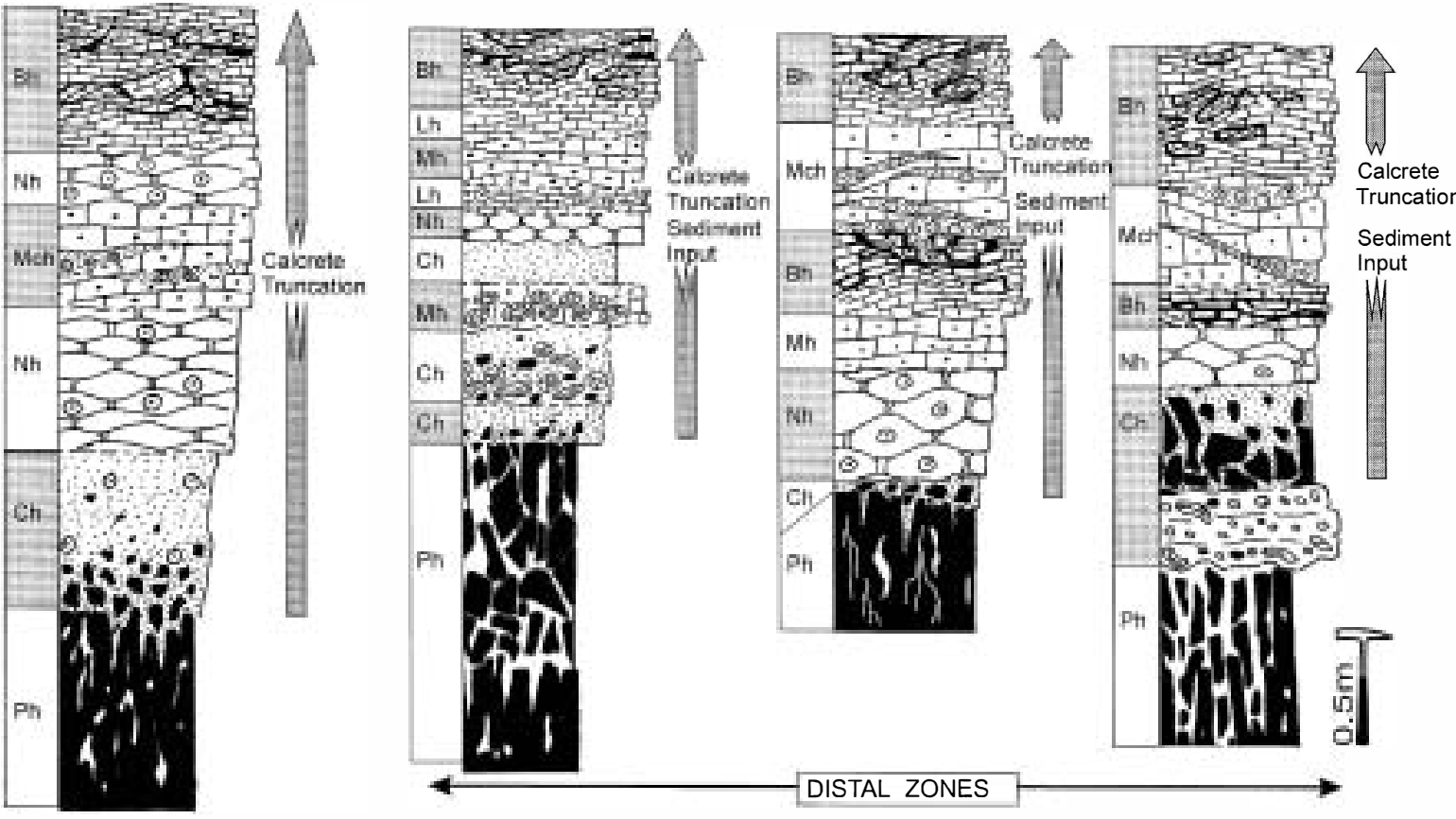
Input
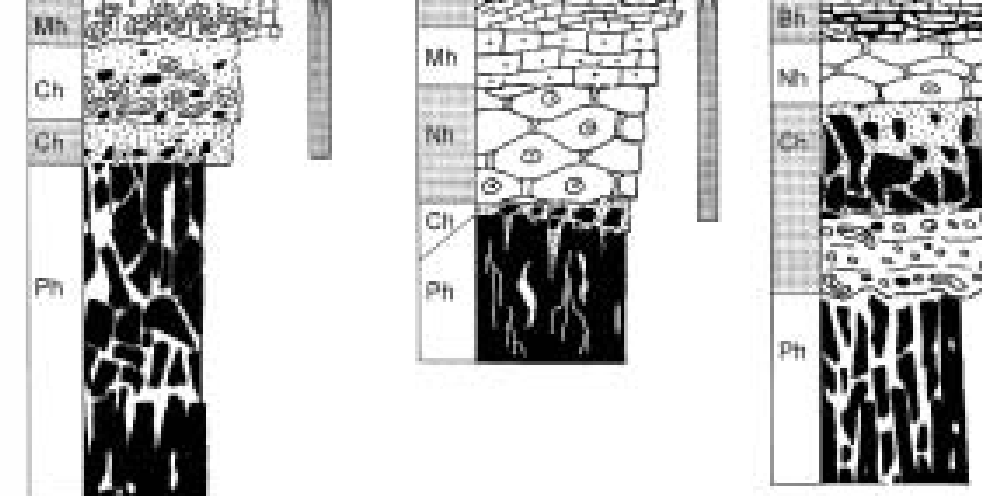

DISTAL ZONES

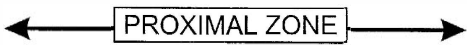

$\begin{array}{cll}\text { Bh } & \text { Brecciated Horizon } & \text { Mch Complex Massive-Chalky Horizon } \\ \text { Lh Laminar Horizon } & \text { Ch Chalky Horizon } \\ \text { Mh } & \text { Massive Horizon } & \text { Ph Prismatic transitional Horizon } \\ \text { Nh } & \text { Nodular Horizon } & \end{array}$

Fig. 4. Sections of selected calcrete profiles, showing the arrangement of the different horizons. For location see Fig. 2.

massive, coated gravel and laminar horizons reported by previous authors (Gile et al., 1966; Esteban and Klappa, 1983; Machette, 1985). However, the association of the different horizons does not always result in the typical or characteristic calcrete profiles described by those authors. Not all the profiles contain the six horizons and in distal areas, some horizons, especially the chalky, massive and laminar horizons, may occur in different positions within the calcrete, giving rise to complex composite profiles (Fig. 3B and Fig. 4). Thus, by the term profile, we describe the whole association of horizons without considering if it is a single or composite profile.

\subsection{Prismatic horizon}

In most cases, the calcretes and specifically this type of horizon are developed on reddened sands and

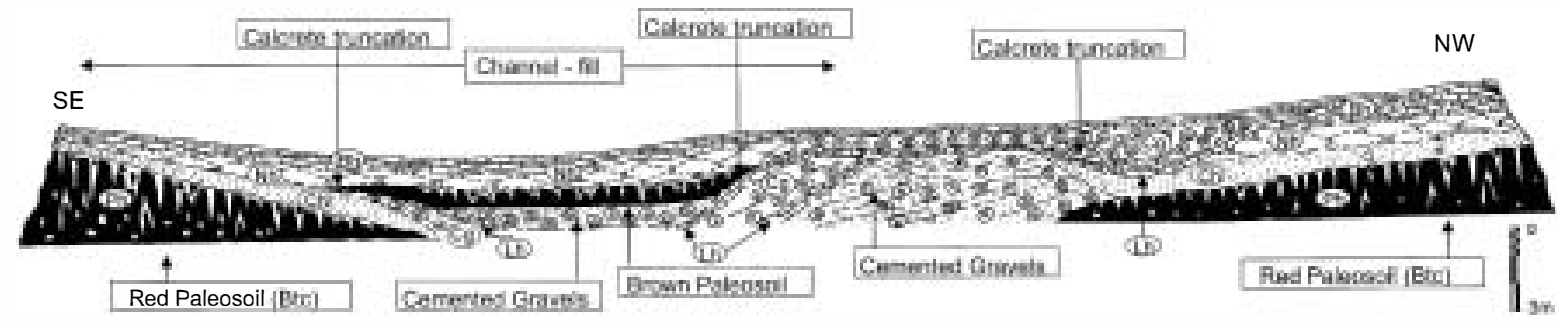

Fig. 5. Cross-section of the railway cut showing the distribution of calcrete profiles and/horizons in the proximal fan area (T18 in Fig. 2). 
clays. The sands are mainly litharenites with fragments of metamorphic rocks. The clays occur as individual beds or as the matrix of the sand deposits. The hosts show prismatic structures with prominent cutanic features developed along the vertical cracks that delineate the prisms.

The prismatic horizon forms the base of all the studied profiles and lies directly on the host rock or substrate, so it is the transitional horizon from the host to the upper, mostly carbonate, horizons. The thickness varies from 0.5 to $1.25 \mathrm{~m}$. It is composed of vertically elongated carbonate nodules up to 30 $\mathrm{cm}$ long and about $8 \mathrm{~cm}$ in width. The carbonate content increases progressively upward, so in the base of the horizon the nodules are disconnected from each other and separated by red clays. At the top of the horizon, most of the nodules are in contact and little clay or sand can be recognised between them.

The carbonate nodules consist of sands and clays cemented by white carbonate. Illuviation cutans are common in some grains. Vertical cracks, probably due to root penetration, are filled by fime grained peloids. Horizontal cracks up to $2 \mathrm{~mm}$ in width and several $\mathrm{cm}$ long occur along the nodules. The nodules show a fime network of cracks, due to desiccation processes or to root penetration. The microfabric of the horizon consists of etched detrital grains floating in a micrite-microspar matrix with usually empty cracks (Fig. 6A).

\subsection{Chalky horizon}

This is a soft horizon whose thickness varies between 15 and $80 \mathrm{~cm}$ and mostly lies on the prismatic horizons, but also occurs, directly within the host rock or interstratified within the massive horizons (see below). The base of the horizon is commonly very irregular so the geometry is wavy or lenticular with abrupt changes in thickness.

The microfabric consists of a micrite and/or microspar matrix with etched detrital grains and peloids. The peloids are rounded and about $0.75 \mathrm{~mm}$ in diameter. They were formed by a nucleus, made of a detrital grain or root debris and micritic laminated coatings (Fig. 6B). The coatings are usually dark and regular with different laminae, formed by dark mi- crite with few detrital grains and by lighter micrite with more detrital grains and prismatic calcite crystals, up to $20 \mu \mathrm{m}$ in size. This horizon shows a number of desiccation (Fig. 6B) and root cracks. Alveolar septal structures are very common within the cracks, in the nucleus of the peloids and bordering the peloids. The occurrence of the peloids results in a granular appearance. In cases where these horizons develop within massive horizons, they show the same petrographical characteristics, except that they commonly include reworked fragments of laminar horizons.

\subsection{Nodular horizon}

The nodular horizon lies on the prismatic and/or chalky horizons and is usually overlaid by the massive or laminar horizons (Figs. 4 and 5). The thickness of the horizon averages $0.4 \mathrm{~m}$. They consist of carbonate nodules about $6 \mathrm{~cm}$ in diameter. The nodules are relatively harder than the surrounding matrix, which is usually made of chalky limestone or red clays. The nodules vary in morphology between vertical, horizontal, irregular or even branched. This horizon differs from the prismatic horizon in terms of morphology of the nodules and the lack of clay between the nodules.

Microscopically, the horizon is composed of micrite, rich in etched detrital grains (up to 20\%) of quartz and fragments of sedimentary and low grade metamorphic rocks. The detrital grains are usually coated by laminated micrite in which the different laminae are composed of either dark and dense micrite, micrite and microspar, or by brownish micrite due to the presence of clay (palygorskite). Some fragments of dense micrite also occur within the micrite matrix.

\subsection{Massive horizon}

This horizon commonly overlies the nodular or chalky horizons and underlies the laminar one (Figs. 4 and 5). The thickness of this horizon averages 0.5 $\mathrm{m}$. It is very indurated. Two different types of massive horizons have been recognised. In the proximal areas, they consist of a relatively homogeneous micrite-microspar matrix with few detrital grains and 

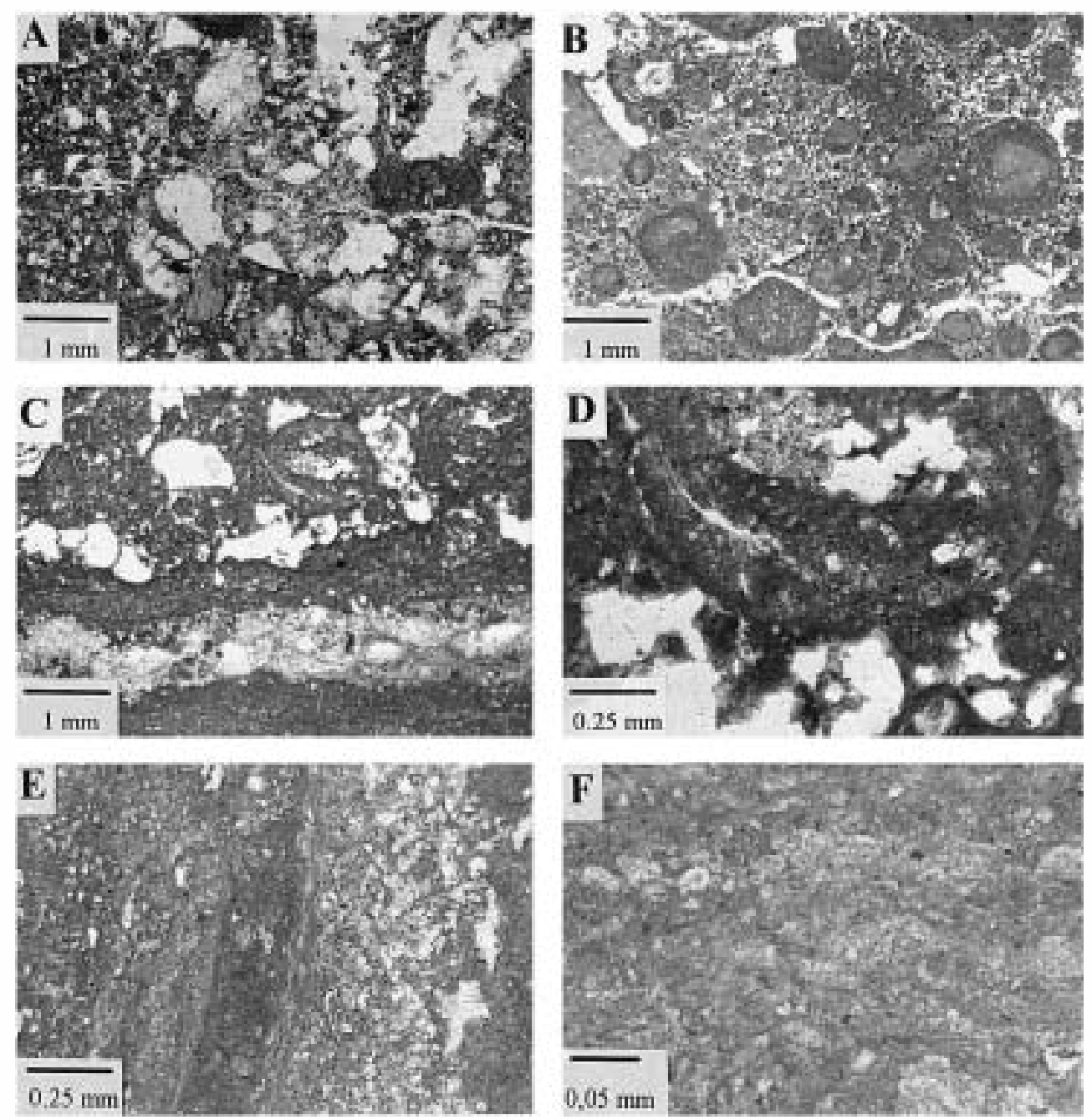

Fig. 6. Microphotographs of thin section of calcretes. (A) Prismatic horizon. Detrital grains are embedded in micrite. Some relict clays from a previous Bt horizon are recognised. (B) Chalky horizon. Micritic coated grains resulting in a granular fabric. The nucleus of the grains is formed by light micrite, whereas in the coatings, micrite is denser. Coatings are very irregular. (C) Massive horizons of the calcrete are forme by dense micrite, with microsparitic laminae showing alveolar septal structure and micritic coated grains. Detrital grains are also present. (D) Detailed view of C. Alveolar septal structure occurs in the nuclei of the grains, as well as in the surrounding matrix. The coatings of the grain contain silt-sized detrital grains. (E) Laminar microfabric is formed of an alternation of micrite and microspar laminae. The contact between them is very irregular and some microspar-sized crystals are included within the micrite. (F) Laminar microfabric contains spherulites arranged in irregular bands.

micritic peloids, usually lacking laminated micritic coatings. In this case, the peloids consist mostly of dense micrite, and their morphology varies from rounded to very angular. The matrix shows a network of planar cracks, several millimetres wide and alveolar septal structures.
In the distal areas, the massive horizons also occur overlying and degrading previous laminar horizons. This causes a clear disruption of the classic sequential arrangement of calcrete profiles described by Gile et al. (1966) and Machette (1985). The main distinctive feature of these kinds of horizons, is that 
they are interstratified with centimetre laminae of a chalky nature, displaying in all cases a basal chalky zone, of variable thickness, with a fine-grained basal lag of metamorphic clasts and reworked angular fragments of previous laminar horizons. This indicates that these atypical massive horizons are developed in relation to sedimentary disruptions, when new fime veneers of sediments $(0.2-0.4 \mathrm{~m})$ are deposited in distal zones, truncating the underlying laminar horizon and generating new available space for calcrete development. Commonly, this kind of horizon vertically evolves to typical massive horizons overlaid by a laminar horizon. Some lamination is also recognised. The laminated areas are about 3 $\mathrm{mm}$ in thickness and occur isolated within a dense micrite, that includes rounded grains with micritic coatings. The laminae within the coated micritic grains (Fig. 6C,D), as well as within the larger laminated areas, are very irregular and consist of light laminae formed by microspar altemating with darker laminae made of micrite with some etched detrital grains and loose microspar crystals. In both proximal and distal areas, alveolar septal structures occur within any of the laminae as well as in the dense micrite matrix. This matrix is relatively porous due to the occurrence of small tubiform pores, up to $1 \mathrm{~mm}$ in diameter, generated by root accommodation.

\subsection{Horizons formed of coated gravels}

These horizons occur only in the profiles of proximal alluvial fan areas, in the Venta Seca and railway outcrops (Figs. 4 and 5). They commonly substitute or are laterally linked to the massive horizons in these proximal areas, being overlain by laminar horizons. They are developed on gravel deposits, that consist of angular to rounded clasts 0.3 to $2 \mathrm{~cm}$ in diameter. Clasts are mostly of carbonates (limestones and dolostones) and metamorphic rocks. Occasionally, some very angular calcrete clasts sourced from lower calcrete horizons occur. The base and top of these horizons are usually sharp, with the base being irregular and the top, planar. The irregular base is a relic feature, which indicates that this kind of carbonate accumulation is mainly accommodated to the geometry of charmel-like bodies. Therefore, the thickness and extent of these horizons are variable, from 0.1 to $1.5 \mathrm{~m}$ in depth and $5-12 \mathrm{~m}$ of lateral extent. The horizon is very indurated and is formed by clasts coated by reddened carbonate laminae. The laminae usually coat all the clasts, although, they are relatively asymmetrical, being thicker on the lower part of the clast than on the upper part. The laminae are composed of dense micrite, micrite with alveolar structure and/or microspar. The coated clasts are embedded in a dense matrix that consists of irregular masses of microspar including some detrital grains and micrite with alveolar septal structure.

\subsection{Laminar horizon}

This horizon is usually the topmost horizon of the profile, overlying massive or nodular horizons. The thickness reaches up to $0.9 \mathrm{~m}$ in the profiles, developed in distal areas. However, in the proximal areas the horizon is thinner or may be absent. This contrasting thickness and/or occurrence seems to be directly linked to the fan-surface dynamics during the last stages of fan development. Thicker laminar horizons in distal areas, dominated by limited aggradation, is the result of episodic sedimentation generating new space for calcrete development. In proximal areas, dominated by channel trenching and dissection below the fan surface, sediment input is absent or very reduced, resulting in calcrete reworking and degradation, and leading to the occurrence of thinner laminar horizons. In the distal areas, this horizon also occurs intercalated within the profile and not only as the topmost layer. In this case, they are thinner (up to $0.25 \mathrm{~mm}$ ) and overlain by the chalky-massive interstratified horizons linked to sedimentary inputs. The lamination is clear at different scales. Macroscopically, laminae of 3 to $10 \mathrm{~cm}$ thick are clearly distinguished and have a wavy and contorted appearance. At more detailed scales, the laminae are of $0.5-1 \mathrm{~cm}$ thick and consist of alternations of smaller scale, dense and porous, micritic layers and grains with micritic coatings (Fig. 6E). Microscopically, up to five different types of laminae may be present: micritic layers, micritic layers with fime tubiform pores, laminae very rich in alveolar septal structures, microsparitic laminae and laminae including micritic coated grains.

At the top, these laminar horizons are commonly both brecciated and indurated, so that angular frag- 
ments of the laminated horizons are included as clasts, that are coated by new and discordant laminae of millimetre scale. Stages of brecciation and/or reworking and coating have been repeated through time, as the fragments show different sets of discordant laminae, that cut previous ones. The unconsolidated caliche rubble degrading the topmost part of these horizons, could represent the incipient stage of a new period of calcrete brecciation. This indicates that near-surface plant root mechanical weathering may have induced the calcrete disagregation.

\section{Characteristic features}

Detailed analyses of thin sections, as well as SEM have shown, that most of the horizons present some features whose occurrence may be a good indicator of processes operating in calcrete formation. These features are described below.

\subsection{Alveolar septal structures and calcified fila- ments}

They are present in all the profiles studied and in most of the horizons. They occur in pores, bordering or within the laminae of coated grains and forming some of the layers of the laminar horizon. They consist of a network of micritic septa (Fig. 6C,D), whose voids are, in some cases, cemented by calcite spar. Under the SEM, the septa are seen as calcified filaments $100 \mu \mathrm{m}$ long and $2-5 \mu \mathrm{m}$ in diameter (Fig. 7A). Alveolar septal structures are commonly recognised in calcretes as well as palustrine limestones and their formation is considered to be the result of fungal activity in symbiotic association with roots (Wright, 1986).

Calcified filaments occur not only in the alveolar septal structures, but also in the micritic coatings of some grains and as bridges between them. They are relatively straight, although some are curved or sinuous. Usually, they can be seen as one single calcified filament, but Y-shaped branching has been observed (Fig. 7B,C). The filaments are connected to each other (Fig. 7D,E) in a very irregular way, and sometimes they are also connected with spherical bodies about $100 \mu \mathrm{m}$ in diameter. The calcified filaments consist of a dense packing of rhombohedral-shaped crystals, $1 \mu \mathrm{m}$ in size, probably of calcite but calcium oxalate cannot be excluded. In some cases, longer crystals up to $10 \mu \mathrm{m}$ long and $2 \mu \mathrm{m}$ wide, grow perpendicularly to the filament (Fig. 7A). These crystals could have been initially of calcium oxalate, according to crystal morphologies described by Verrecchia et al. (1993). Calcified filaments have been recognised very often within calcretes of different ages (James, 1972; Kahle, 1977; Klappa, 1979a; Phillips et al., 1987). Most authors consider that, the filaments are calcified fungal filaments, although this is not a direct interpretation as the precipitation of calcite or calcium oxalate erases most of their microstructure and morphology. However, the recognition of branching and the morphology of the rare non-calcified filaments (Fig. 7B,C) in the studied calcretes suggest a fungal origin for them. Moreover, crystal morphologies are similar to those described by Verrecchia et al. (1993) for the initial stages of fungal biomineralization.

\subsection{Coated grains}

Two types of coated grains are observed in the studied profiles: (a) detrital grains (metamorphic or sedimentary rock fragments) that show very irregular micritic laminated coatings. Some of the laminae are solely formed by alveolar septal structures. The size of the grains varies from $0.3 \mathrm{~mm}$ to $4 \mathrm{~cm}$ and depends on the original size of the detrital grain. The micritic coating is thinner than the detrital grain. The coatings show different colours due to the varied proportions of clays (mostly palygorskite) and finer detrital grains. (b) Coated grains in which the nucleus is formed either by homogeneous or laminated micrite or by alveolar septal structure (Fig. 6B,D). Moreover, in some cases, the grains are solely formed by coatings lacking a visible non-laminated nucleus. The coatings are usually, relatively, regular and tend to be spherical. The mean size of the grains is $1 \mathrm{~mm}$. The coatings are formed from dense micrite, including brown clays (palygorskite), alveolar septal structures and microspar. They vary in colour from white to pale brown. The contact between the coated grain and the surrounding matrix varies from being outlined by circumgranular cracks to very diffuse or gradual. 
The occurrence of alveolar septal structures, calcified filaments (Fig. 7E), detrital grains and clays as well as the lack of larger calcite crystals make these
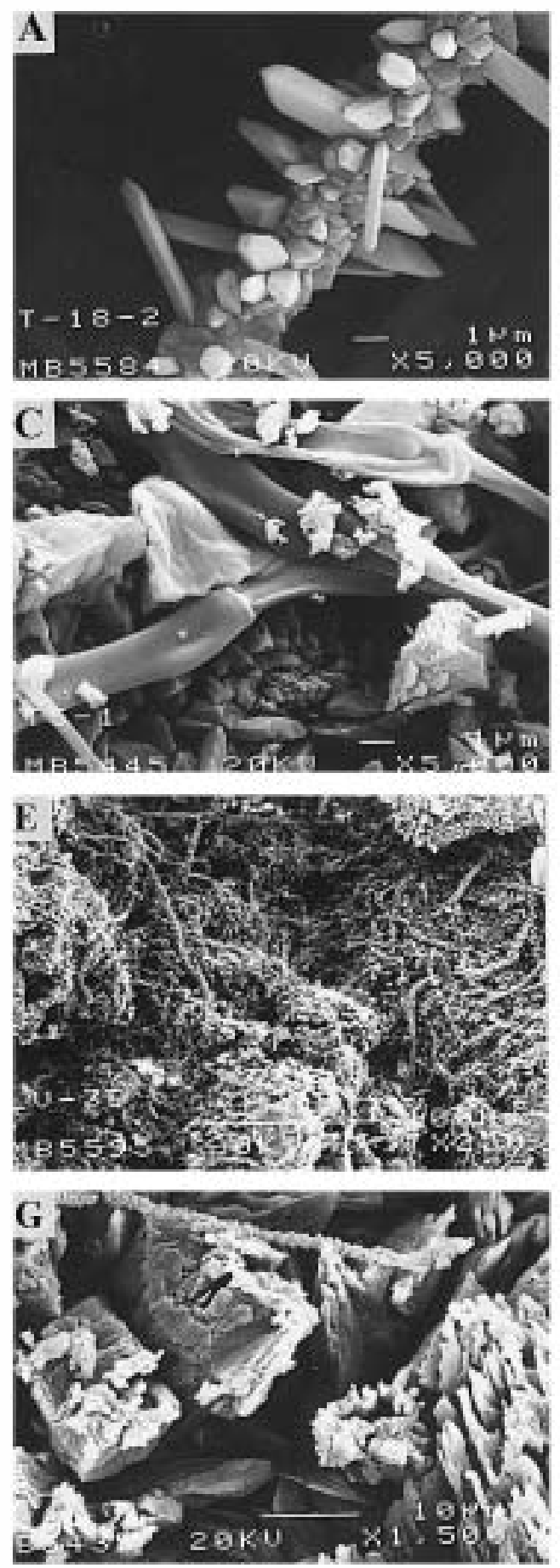

grains very different from other coated grains such as oncoids, cave pearls or ooids, amongst others. Coated grains similar to those described in this study
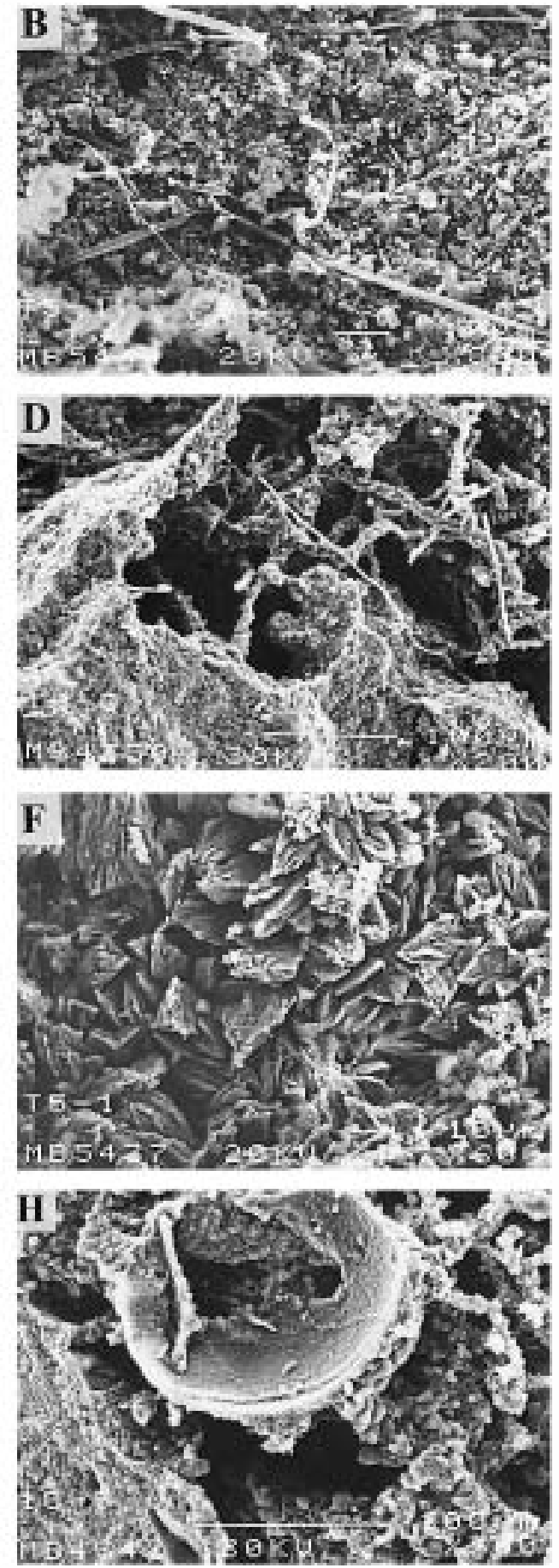
have been commonly recognised in calcretes (Calvet and Julia, 1983; Wright, 1986), palustrine carbonate (Freytet and Plaziat, 1982; Wells, 1983) and peritidal settings (Mazullo and Birdwell, 1989). The formation of these grains requires the individualisation of the nuclei either by desiccation or root activity as described by Alonso-Zarza et al. (1992) and the formation of the coating. The formation of the micrite envelopes seems to be controlled by biogenic activity of roots and associated microorganisms, specially fungal filaments (Fig. 7E) (Calvet and Julia, 1983; Alonso-Zarza et al., 1992; Jones, 1987).

In this study, the process of coating formation is more complex, as reflected in the occurrence of palygorskite and the diffuse boundaries between nuclei and coatings and coatings and matrix, observed in some of our examples. The incorporation of siltsized detrital grains (Fig. 6D) within the coatings, may indicate that the nuclei rolled within the soil and thus, could incorporate any loose component of the soil. The rolling of the grains could be favoured by the growth of roots or root hairs. Both the precipitation of carbonate in relation to the organic filaments and the rolling of the clasts explain the morphology and composition of the coated grains. Moreover, precipitation of micrite in the grain boundaries and in the surrounding matrix favoured the formation of diffuse boundaries. The presence of palygorskite mixed with micrite in some of the coatings has also been recognised by Hay and Wiggins (1980) in peloids and ooids of Quatemary calcretes developed on volcanic host-rock. They considered that, palygorskite was formed as a replacement of $\mathrm{Al}$-rich detrital clays. Formation of authigenic clays, such as palygorskite and sepiolite in calcretes, is the result of Mg-enrichment of the vadose waters after the precipitation of Low Mg Calcite in the calcrete (Watts, 1980).

\subsection{Microspar and pseudospar calcite}

Microspar and pseudospar-sized calcite crystals occur mostly in the massive and laminar horizons. They are usually present as irregular bands averaging $0.2 \mathrm{~mm}$ in width that alternate with micrite laminae. The boundaries of the bands tend to be sharp but very irregular (Fig. 6E,F), although some diffusegradual transitions from micrite to microspar are present. Isolated patches of micrite within the microspar and pseudospar are common and in the same way patches or even individual microspar crystals are present within the micrite.

The microspar crystals are about $15 \mu \mathrm{m}$ long and about $10 \mu \mathrm{m}$ wide. They occur either with their longer axes perpendicular to the general lamination or completely disorganised and lacking any type of orientation (Fig. 7F). They are mostly anhedral and under SEM clear dissolution features following cleavage of the crystals are recognised (Fig. 7G). Filaments, mucilaginous sheaths as well as rods of bacteria are present on the surface of some calcite crystals (Fig. 7G).

The origin of microspar and pseudospar in vadose environments is unclear. Tandon and Friend (1989) have suggested that it may be the result of early recrystallization processes. However, the anhedral morphologies, the dissolution features and the occurrence of organic structures on some crystals indicated that micro and pseudospar may not only be the product of recrystallization process, but may also be due to multiple phases of growth and dissolution (Wright and Peeters, 1989) or to processes of displacive and non-uniform growth (Saigal and Walkdon, 1988). Moreover, in our case, the occurrence of the organic structures could contribute to the dissolution, weathering and precipitation of the crystals and even to the disaggregation of the microspar and

\footnotetext{
Fig. 7. S.E.M. images. (A) Calcified filaments in which short parallelepiped crystals co-exist with longer ones. These morphologies seem to represent the earliest stages of calcification by weddellite (see Verrecchia et al., 1993). (B) Network of non-calcified filaments, probably of fungi growing amongst the microspar crystals. (C) Detailed view of B, septa within the filaments are neatly observed. (D) Alveolar septal structure. Calcified filaments leaving wide pores between them. In this case, no calcite cement is filling the porosity. (E) Micrite envelopes of coated grains. Much of the coatings are formed by calcified filaments that are interconnected between them. (F) View of microspar laminae calcified and/not calcified filaments occurring between the crystals. The microspar crystals are very anhedral and their faces show dissolution features. (G) Microspar larninae showing clear dissolution features along calcite cleavage plames. Filaments containing spherical bodies, probably bacteria, are shown. (H) Spherical to ovoidal body, surrounded by a network of calcified filaments. It corresponds to a fungal peritecium.
} 
pseudospar masses and/or laminae, favouring their incorporation within the micrite laminae. Jones (1988) have also described calcite crystals that underwent diagenetic processes, controlled by microbial activity in Pleistocene caliches of the Cayman Islands.

- ther structures such as spherulites, calcified cells and calcispheres are also present in the calcretes. Spherulites are spherical bodies $100 \mu \mathrm{m}$ in diameter and show fibro-radial textures. They occur very sparsely (less than $1 \%$ of the total calcrete) in the calcretes (Fig. 6F), mainly in the topmost layers. Spherulites have been commonly recognised in calcretes (Verrecchia et al., 1991; Fedoroff et al., 1994; Sanz, 1996) and have even been grown experimentally (Verrecchia et al., 1991, 1995). In all cases, a microbial origin is inferred for these stuctures. Differences in interpretation by different authors exist as to the type of organisms and the place in the calcrete where they are produced. Monger et al. (1991) indicated that they formed in association with bacteria and fungi, so that no light will be needed and they can form inside the calcrete. Fedoroff et al. (1994) and Verrecchia et al. (1995), however, consider that they form in cyanobacterial mats and they need direct light exposure. We do not have enough data to test the validity of the two interpretations, but the fact that, in the calcretes that were analysed, the spherulites are sparse and only in two cases they form laminae up to $2 \mathrm{~cm}$ long and $0.2 \mathrm{~mm}$ wide. Fig. $6 \mathrm{~F}$ suggests that most probably, they could be formed at the calcrete-amosphere surface and were later introduced within the calcrete by roots or simply by mechanical reworking. Reworking of spherulite laminae could also be a source of the microspar and pseudospar sized crystals.

Calcified cells occur as spherulites, very sparsely and have only been recognised under SEM. They are round to polygonal crystals and about $4 \mu \mathrm{m}$ in diameter and with a central pore of $2 \mu \mathrm{m}$, suggesting that calcification occurred at the cell walls, as is also seen in some of the calcrete profiles of the Madrid Basin (Alonso-Zarza et al., 1998).

Calcispheres are about $150 \mu \mathrm{m}$ in diameter. They are different from spherulites, as they consist only of a calcite cortex of about $5 \mu \mathrm{m}$ in thickness, surrounding a central cavity. The calcispheres are spherical to ovoid and they show a small peak that expands outside (Fig. $7 \mathrm{H}$ ). The crystals that form the walls are prismatic to isodiametric in form and in the inner and outer walls, calcite crystals up to $5 \mu \mathrm{m}$ in size are present as cements. The calcispheres are connected with a network of calcified filaments (Fig. $7 \mathrm{H}$ ), which suggests that they may be fruiting bodies of fungi (perithecium).

\section{Interpretation}

The Pleistocene fan surface calcretes studied here, show features such as calcified filaments, coated grains, rhizoliths, alveolar septal structures and peloids that are commonly recognised in biogenic or $\beta$-calcretes (Wright, 1991). The recognition of different horizons and the occurrence of rhizoliths and alveolar septal structures are indicative that most carbonate accumulation occurs in the soil, as 'classically' considered by (Gile et al., 1966; Esteban and Klappa, 1983; Machette, 1985; Mack and James, 1992), but it is mainly induced or accelerated by the activity of root plants. However, some of the structures reported here, such as spherulites, could also develop at the soil atmosphere surface (Verrecchia et al., 1995).

It has also been stated, that thick mature calcretes were formed as a result of multiple stages of soil formation, erosion and reworking (Fedoroff et al., 1994; Sanz and Wright, 1994). In this study, the occurrence of micro-pseudospar calcite crystals, adhesion of clays and silt-sized detrital grains in the micrite, spherulites either in small laminae or rarely within the calcrete and brecciated laminar horizons, indicate that these calcretes do not represent a unique and continuous stage of soil formation, but that degradation, reworking and exposure of some previously formed horizons (mainly the laminar horizon) occurred throughout calcrete development, especially in distal areas. At the macroscale, these processes are clearly highlighted by the occurrence of sedimentary disruptions linked to the development of massivechalky interbedded horizons overlying laminar horizons, and giving rise to composite profiles.

Calcrete development was initially nucleated along the prismatic structures of the previous red alluvial soil (Bt horizons), which controlled the morphology of the carbonate accumulation within the soil during 
the earlier stages of development. In general, the formation of the thick calcrete profiles took place in different more or less well differentiated stages that, in some cases, were repeated over time. In other cases, one single stage may include several phases of erosion and soil formation, but the main processes occurring at any precise stage are clearly seen at the macroscale. Main stages are (Fig. 8):

\subsection{Stage 1}

Formation of the transitional horizon. The $\mathrm{Bt}$ horizon of the previous soil is overlain by detrital sediments varying from clays to gravels. Vegetation colonised the sediments and roots reached the discontinuities between the prisms of Bt horizons. Carbonate precipitation starts along roots and root hairs that follow the boundaries between the different prisms, resulting in a mainly vertical control of carbonate accumulation.

\subsection{Stage 2}

Formation of a chalky horizon. This horizon is mostly formed by peloids and coated grains which have been commonly recognised in close relation with root and root hairs (Calvet and Julia, 1983; Jones and Squair, 1989). At this stage, carbonate precipitation takes place only in discontinuous areas in sites occupied by roots.

\subsection{Stage 3}

Increased carbonate precipitation around roots, results in the formation of hard carbonate nodules of variable size and morphology. The transition between chalky and nodular horizons is progressive. Subsequent vertical evolution of nodule growth is characterised by partial coalescence of nodules giving rise to a hardened, but still friable, nodular horizon.

\subsection{Stage 4}

Carbonate precipitation is very intense and does not only follow root structures, but also occurs throughout the uppermost part of the $\mathrm{K}$ horizon. At this stage, precipitation of micrite and micro and pseudospar displace the previous sediments and give

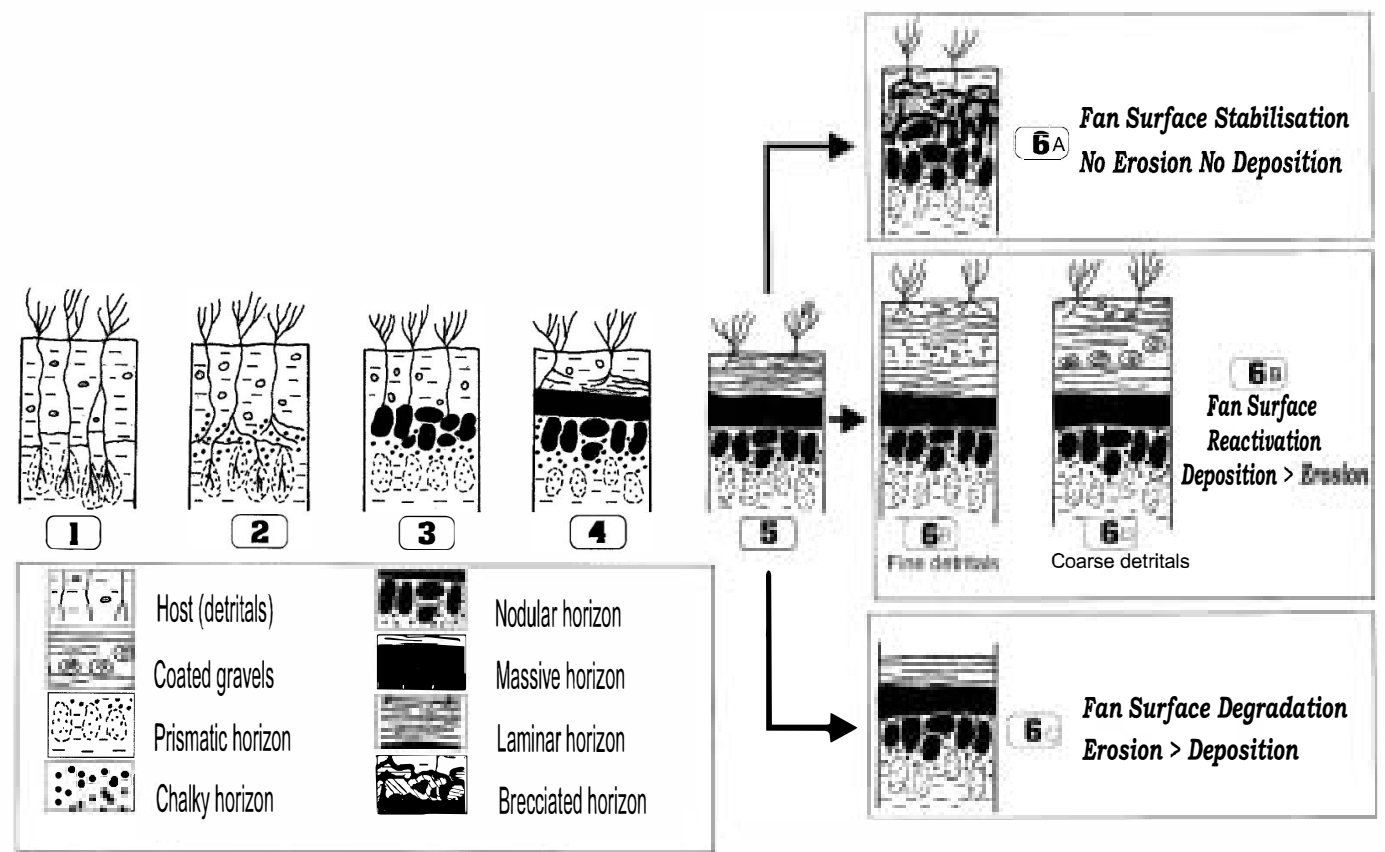

Fig. 8. Model for the formation of different calcrete profiles in the study area. For Stage 6, different erosion/sedimentation relations are envisaged as well as different host sediments. See text for detailed explanation. 
rise to the formation of the massive horizon by growth and coalescence of individual nodules at different scales. During this stage, the $\mathrm{K}$ horizon is progressively indurated and porosity is drastically reduced, promoting a near-impermeabilization of this level, which inhibits the infiltration of meteoric waters, leading to the occurrence of perched and episodic micro-water tables above it.

\subsection{Stage 5}

Root systems cannot easily penetrate the indurated massive horizon. In addition, water is mainly confimed to the uppermost part of the profile in the still unconsolidated zone above the massive horizon, so that the geometric pattern of root growth changes. Plant roots, looking for water, tend to extend laterally, promoting the development of sub-horizontal root networks. The laminar horizon starts to form in the still unconsolidated uppermost zone. A similar effect has been described for the transition between nodular and platy horizons (Esteban and Klappa, 1983). The degree of development, characteristics and thickness of this horizon, depends on the time that the root systems are able to be supported either in the upper soil horizon or by the new detrital deposits. In this last case, new sediment inputs generate additional available space for calcrete growth, leading to the occurrence of thick laminar horizons. From this stage, calcrete formation can follow different paths, depending on the relation between calcrete formation and erosion/sedimentation processes linked to the latest phases of fan surface development (Fig. 9). We refer to the next stages as 6A, 6B and $6 \mathrm{C}$.

\subsection{Stage $6 A$}

Erosion and sedimentation do not occur or the balance between them is close to zero. In this case, reworking and brecciation of the laminar horizon or of the whole profile take place. This would be the case for calcrete profiles located in proximal fan settings away from fan surface charmels during late stages of fan development. But also, these conditions control broad areas of the fan surfaces today, especially those in inter-gully locations in distal zones. Plant roots induces mechanical weathering, degrada- tion and reworking of the topmost laminar horizon, which results in the development of what is presently unconsolidated caliche rubble, probably representing an early stage in the formation of indurated brecciated horizons. Also, very limited deposition, promoted by surface runoff after episodic stormy events may contribute to the development of these thin unconsolidated formations on the fan surface.

\subsection{Stage $6 B$}

Deposition is greater than erosion, but is episodic, contributing new surface sediments for plant establishment and subsequent development of new root networks. Episodic deposition is recorded in distal fan locations, disrupting the sequential evolution of the calcrete profiles and leading to the development of a new profile, thus generating composite profiles. In these zones, where new deposition is characterised by fime-grained sediments, new complex chalkymassive interbedded horizons overlain by laminar and brecciated horizons may be formed. If the sediments are coarse gravels, as occurs in channel fillings at proximal locations, coated gravel horizons form the base of the subsequent profile after erosion and brecciation of the previous laminar horizon. No similar conditions are recorded today on fan surfaces.

\subsection{Stage $6 C$}

Erosion rate is higher than sedimentation rate. The upper part of the calcrete profile (B horizon or detritals) is removed and the laminar horizon is directly exposed to the atmosphere. Some spherulites can be formed, and lichens may grow in surficial conditions (Klappa, 1979b). This is the case of the laminar crusts located at the base of gravel charmels in proximal areas, developed after fan head-rench incision, or broad zones of the entire fan surface topmost laminar horizon after the eventual fan abandonment. In this study, this latter process, after proximal channel filling coeval to eventual distal aggradation, promotes the ultimate fan surface planation, giving rise to the present tableland landscape by integration of distal and proximal zones in a single, flat and indurated geomorphic surface. Actually, 


\section{PROXIMAL ZONES $\Longleftarrow$}

\section{FAN DEVELOPMENT}

Earlier more humid conditions Plant colonisation (except channels)

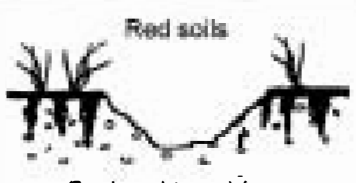

Fanhead trenching
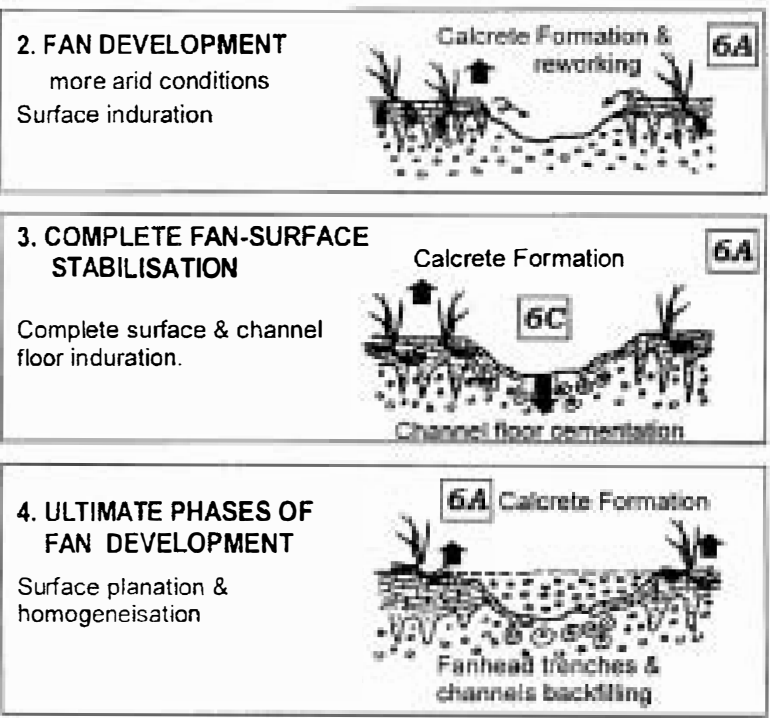

5. EVENTUAL FAN
ABADONEMENT
Surface stabilization \&
induration
$\begin{aligned} & \text { Calcrete subarieal exposure } \\ & \text { reworking \& Brecciation }\end{aligned}$

DISTAL ZONES
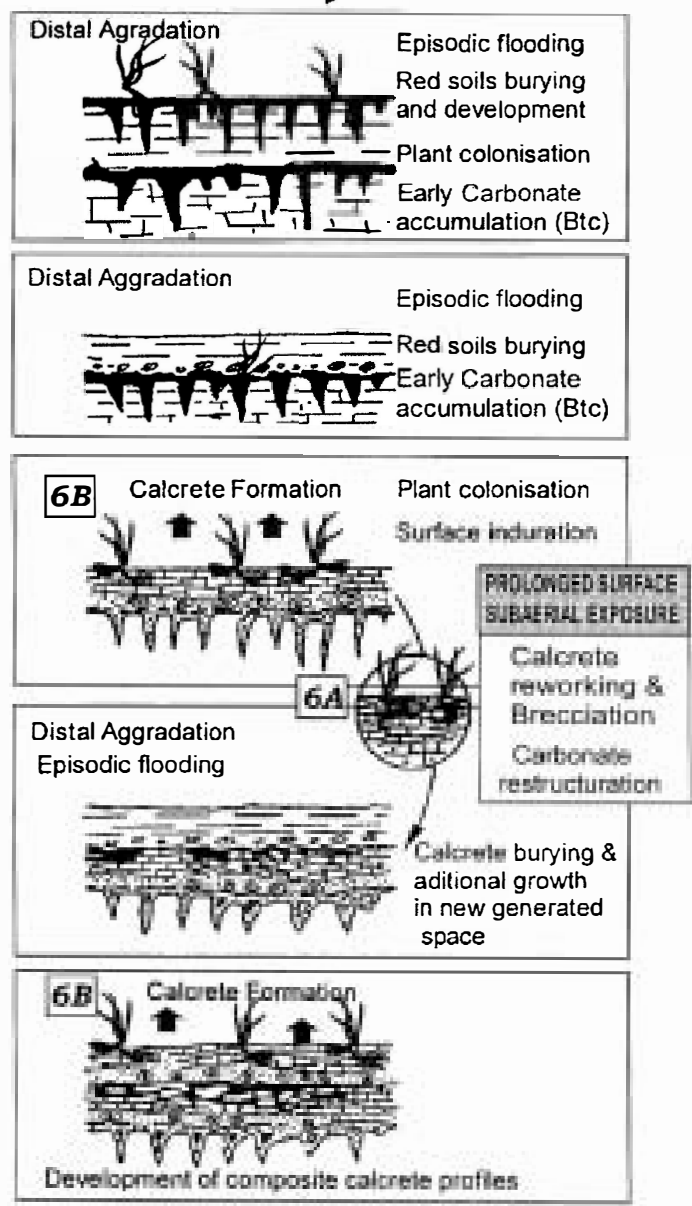

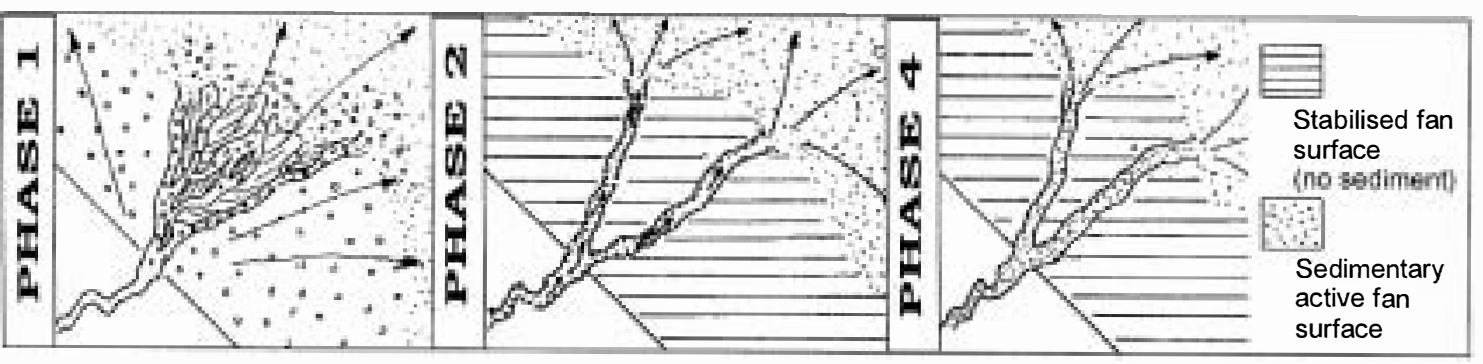

Fig. 9. Model for the interaction of calcrete development, vegetation and fan surface dynamics, both in proximal and distal fan areas.

broad areas of the slightly higher proximal zones have laminar brecciated horizons at surface, suggesting that episodic runoff erosion could have removed earlier overlying weathered materials. Also, in these zones devoid of weathered covers, the occurrence of karstic microforms at the surface is characteristic today.

Stages $6 \mathrm{~A}, 6 \mathrm{~B}$ and $6 \mathrm{C}$ can be developed in the same profile at different times and can even be repeated, especially in distal zones. What results is a 
complex arrangement of horizons and microfabrics, mainly at the top of the profiles, but also within the profiles in relation to previous sedimentary disruptions in distal zones. The development of these three last terminal stages of calcrete formation is showed in Fig. 9, at different fan locations (distal/proximal) and phases of fan development. Stage $6 \mathrm{~A}$ occurs widely at proximal zones during most of the terminal phases of fan development (phases 2 to 5), but always from inset fan channels. In these locations, stage $6 \mathrm{~A}$ only develops after channel filling and subsequent eventual fan abandomnent (phase 5). On the contrary, stage $6 \mathrm{~A}$ is subsequent to previous $6 \mathrm{~B}$ stages in fan distal zones, where episodic sedimentary inputs generate new available space for carbonate accumulation giving rise to calcrete thickening (phases 3 and 5). As illustrated in Fig. 9, this last process only occurs in proximal zones after the eventual filling of inset fan channels (phase 5). Finally, stage $6 \mathrm{C}$ only develops in the floor of inset fan charmel and in proximal locations. Stage 6C operates today over broad areas of the fan surfaces after strong storm events, triggering fan surface degradation (erosion + karstification) through the reworking of caliche rubble generated during the periods of stabilisation (stage $6 \mathrm{~A}$ ).

\section{Discussion and conclusions}

This study highlights the interaction between fan dynamics, surface hydrology, plant root growth and calcrete development. Carbonate accumulation, driven by microbial activity related to plant roots, interacts with root growth patterns and fan surface hydrology. The first stages seem to be controlled by the vertical growth of roots and the infiltration of meteoric waters, resulting in the occurrence of nodules. Subsequent nodule coalescence promotes a reduction in soil porosity and the generation of a near-impermeable indurated subsurface level (massive horizon). Infiltration diminishes, leading to the generation of near-surface thin episodic water layers, so roots tend to accommodate to the new conditions and grow in horizontal networks, confimed at the topmost unconsolidated part of the still evolving profile. In this enviromnent, multiple laminar crusts develop, following the root paths. The growth and thickness of this laminar horizon is directly controlled by the initial available space in the unconsolidated topmost part of the profile. As multiple sets of laminae develop, progressive induration occurs. New root networks tend to shift towards the profile top, and eventually complete surface induration can occur, leading to the subaerial exposure of the laminar horizons. At this stage, the formation of some laminae within ponded zones can take place. Complete surface hardening drastically restricts root growth at depth, so plants tend to rework the laminar crusts, via mechanical weathering, resulting in multiples phases of brecciation as carbonate is accumulated among the broken calcrete fragments, again following these new root paths. Only in distal zones, where inputs of new sediment from proximal entrenched channels generate new available space for plant accommodation, can calcretes continue to grow. This leads to the occurrence of thicker, but complex, profiles, characterised by laminar horizon truncation and subsequent development of rare interbedded chalky-massive horizons, which rapidly evolve to form a new laminar horizon.

The stages of calcrete development proposed here, are not very different from those described by Gile et al. (1966); Esteban and Klappa (1983) or Machette (1985), amongst others, but it is important that in the calcretes studied, the profile is not a single profile and that in the same profile, different phases of erosion and/or deposition are needed to form a mature calcrete profile as those described here. The proposed model also considers the possibility that at some later stages, calcrete development could occur on subaerial exposure with no B horizon or detrital sediment overlying the laminar crust. Moreover, the role of vegetation in carbonate accumulation, via root activity, is important in all the horizons described, as can be inferred from the microstructures and microfabrics identified in the petrological analysis, so it seems to be obvious that plant colonisation of fan surfaces is a basic requirement for the development of thick mature calcretes.

The types of plant on these fan surfaces, since at least the late Pleistocene, corresponds to xeroesclerofile bushes of Artemisia and Chenopodiacea species, as suggested by nearby palynological records (Munuera and Carrión, 1991). These steppe-type plants are characterised by the development of exten- 
sive root systems, though their occurrence on fan surfaces could be sparse, the roots systems could expand over broad zones and favour extensive carbonate precipitation, restructuration and reworking. These same species indicate that similar semiarid-dry conditions to today's, were operating during calcrete development. Maybe, the fan surficial hydrology could be a more effective factor than climate in controlling water availability and soil-moisture distribution for calcrete development. In this way, even in similar semiarid conditions, if fan inactivity and subsequent dissection reduce the amount of the soil moisture on fan surfaces, available for carbonate precipitation, then reworking and brecciation of the indurated surface may occur.

The occurrence of disruptions to the classic sequence of calcrete development (Gile et al., 1966; Machette, 1985) in fan distal zones is being reported here for the first time. The resulting complex superposition of calcrete profiles is linked to limited distal aggradation during the most recent phases of fan development. Previous authors have highlighted the role of sedimentation in calcrete development, but have always considered altemating periods of sedimentation and carbonate accumulation, to result in the inhibition of calcrete development and subsequent reworking and burying (Montenat, 1981; Verrecchia, 1987), or simply its reworking by dissection-induced surface abandonment during alternating phases of aggradation and dissection in fluvial terrace building (Sancho and Meléndez, 1992). Only Harvey (1984) in the well documented Carrascoy range fans, adjacent to the studied zone (Fig. 1), reports the occurrence of superposition and truncation of main mature fan surface calcretes by more recent weak calcretes mainly developed on the younger fan distal segments. In addition, that author highlights the interaction between calcrete surface induration and fan chamel geometry, reporting the occurrence of major crust-controlled headcut trenches at midfan locations. This last case is more similar to the study case, where episodic coeval sedimentation interacts with carbonate accumulation in distal zones truncating previous calcrete development but, as a whole, favouring calcrete reactivation and thickening. Therefore, even upon reaching a mature stage, calcrete development may start before the eventual abandonment of the fan surface. Colonisation of fan surfaces by vegetation, and variations in the hydrological behaviour of fan surface, after (episodic runoff + sedimentation) but also before (episodic thin water-tables above massive horizons and occasional ponding) the complete abandonment of the fansurface, seem to be the major processes controlling surface hardening, ultimate planation and subsequent homogenisation of proximal and distal fan segments as a single geomorphological surface.

So, fan surface calcretes cannot be envisaged as simple top-surface carbonate accumulations, but as complex feedback systems in which pedogenic, biogenic and sedimentary processes interact in response to the evolving fan-surface geomorphology and dynamics during the terminal phases of fan development in semiarid environments. Paraphrasing Harvey's words, the most distinctive facies of alluvial fans in the semiarid SE Spain are the calcrete crusts. In this way further studies of fan-surface calcretes will be incomplete if fan-surface dynamics are not considered, and vice versa.

\section{Acknowledgements}

We would like to thank A.S. Goudie and K. White for the careful and constructive reviews of the manuscript. We are specially grateful to the editorial work and suggestions made by A.M. Harvey. This study has been supported by the Spanish DGICYT Projects PB95-0946 (USAL) and PB95-0109 (CSIC).

\section{References}

Alonso-Zarza, A.M., Calvo, J.P., del Cura, García, 1992. Palusrine sedimentation and associated features-grainification and pseudo-microkarst-in the Middle Miocene (Internnediate Unit) of the Madrid Basin, Spain. Sediment. Geol. 76, 43-61.

Alonso-Zarza, A.M., Sanz, M.E., Calvo, J.P., Estévez, P., 1998. Calcified root cells in Miocene pedogenic carbonates of the Madrid Basin: evidences for the origin of Microcodium b. Sediment. Geol. 116, 81-97

Calvet, F., Julia, R., 1983. Pisoids in the caliche profiles of Tamragona northeast Spain. In: Peryt, T.M. (Ed.), Coated grains. Springer-Verlag, Berlín, pp. 456-473.

Dumas, B., 1977. Le Levant espagnol: La génése au relief. Thése d'Etat. París. 
Esteban, M., Klappa, C.F., 1983. Subaerial exposure environments. In: Scholle, P.A., Bebout, D.G., Moore, C.H. (Eds.), Carbonate Depositional Environments. Amer. Assoc. Perrol Geol. Memoir 33:1-96.

Fedoroff, N., Country, M.A., Lacroix, E., Oleschko, K., 1994. Calcitic accretion on indurated volcanic materials (examples o tepetates, Altiplano, Mexico). Proc. XVth World Congress, Soil Sci., Acapulco, Vol. 6A, pp. 459-472.

Freytet, P., Plariat, J.C., 1982. Continental carbonate sedimentation and pedogenesis-Late Cretaceous and Early Tertiary of southem France. Contrib. Sedimentol. 12, 213 pp.

Gile, L.H., Petterson, F.F., Grossman, R.B., 1965. The K horizon: a master horizon of carbonate accumulation. Soil Sci. 97, 74-82.

Gile, L.H., Petterson, F.F., Grossman, R.B., 1966. Morphological and genetic sequences of carbonate accumulation in desert soils. Soil Sci. 101, 347-360.

Goudie, AS., 1973. Duricrusts in Tropical and subtropical landscapes. Clarendon Press, Oxford. 174 pp.

Goy, J.L., Zazo, C., Somoza, L., Dabrio, C., 1990. Evolución paleogeográfica de la Depresión de Elche-Cuenca del Bajo Segura (España) durante el Pleistoceno. Estudios Geol. 46, 237-244

Harvey, A.M., 1984. Aggradation and dissection sequences on Spanish alluvial fans: influence on morphological development. Catena 11, 289-304.

Harvey, A.M., 1990. Factors influencing Quaternary alluvial fan development in Southeast Spain. In: Rachocki, A.H., Church, M.J. (Eds.), Alluvial fans, a field approach. Wiley, New York, pp. 247-269.

Hay, R.L., Wiggins, B., 1980. Pellets, ooids, sepiolite and silica in three calcretes of the southwestem United States. Sedimentology $27,559-576$.

James, N.P., 1972. Holocene and Pleistocene crusts (caliche) profiles. Criteria for subaerial exposure. J. Sediment. Petrol. $42,817-836$.

Jones, B., 1987. The alteration of sparry calcite crystals in a vadose setting, Gand Cayman Island. Can. J. Earth Sci 24, 2292-2304.

Jones, B., 1988. The influence of plants and micro-organisms on diagenesis in caliche: example from the Pleistocene Ironshore Formation on Cayman Brac British West Indies. Bull. Can. Pet. Geol. 36, 191-201.

Jones, B., Squair, C.A., 1989. Formation of peloids in plant rootless, Grand Cayman, British West Indies. J. Sediment. Petrol. 59, 1002-1007

Kahle, C.F., 1977. Origin of subaerial Holocene calcareous crusts: role of algae, fungi and sparmicritization. Sedjmentology 24 , 413-435.

Klappa, C.F., 1979a. Calcified filaments in Quatemary calcretes: organo-mineral interactions in the subaerial vadose environment. J. Sediment. Petrol. 49, 955-968.

Klappa, C.F., 1979b. Lichen stromatolites: criterion for subaerial exposure and a mechanism for the formation of laminar calcretes (caliche). J. Sediment. Petrol. 49, 387-400.

Lattman, L.M., 1973. Calcium carbonate cementation of alluvial fans in Southern Nevada. Geol. Soc. Arn. Bull. 84, 3013-3028.
López Gómez, J., López Gómez, A., 1987. Los climas secos de España según la clasificación de Köppen. Papeles Geogf. Física 12, 5-10.

Machette, M.N., 1985. Calcic soils of southwestem United States. In: Weide, C.L. (Ed), Soil and euaternary Geology of the Southwestern United States. Spec. Paper. Geological Society of America, 203, pp. 1-21.

Mack, G.H., James, W.C., 1992. Calcic paleosols of the PlioPleistocene Camp Rice and Palomas Formation, southern Rio Grande rift, USA. Sediment. Geol. 77, 89-10 9.

Mazullo, S.J., Birdwell, B.A., 1989. Syngenetic formation of grainstones and pisolites from fenestral carbonates in peritidal settings. J. Sedjment. Petrol. 59, 605-611.

Monger, H.C., Daugherty, L.A., Lindemann, W.C., Liddell, C.M., 1991. Microbial precipitation of pedogenic calcite. Geology 19, 997-1000.

Montenat, Ch., 1981. Observations nouvelles sur les croûtes calcaires pléistocènes du Sud-Est de l'Espagne (Province d'Alicante et de Murcia). Géologie Méditerranéene 8 (3), 137-154.

Munuera, M., Carrión, S.J., 1991. Palinología de un depósito arqueológico en el sureste ibérico semiárido: Cueva del Algarrobo (Mazarrón Múrcia). Cuatemario Geomorfol. 5, 107-118.

Phillips, S.E., Milnes, A.R., Foster, R.C., 1987. Calcified filaments: an example of biological influences in the formation of calcrete in South Australia. Aust. J. Soil. Sci. 25, 405-428.

Pons, A., Reille, M., 1988. The Holocene and upper Pleistocene pollen record from Padul (Granada, Spain): a new study. Palaeogeogr. Palaeoclimatol. Palaeoecol. 66, 243-263.

Saigal, G.C., Walkdon, E.K., 1988. On the occurrence of displacive calcite in Lower 1d Red Sandstone of Camoustie, Eastern Scotland. J. Sediment. Petrol. 58, 131-135.

Sancho, C., Meléndez, A., 1992. Génesis y significado ambiental de los caliches Pleistocenos de la región del Cinca (Depresión del Ebro). Rev. Soc. Geol. España 5, 81-93.

Sanz, M.E., 1996. Sedimentología de las Formaciones Neógenas del Sur de la Cuenca de Madrid. Monografías. Ministerio de Fomento. CEDEX. Madrid, 245 pp.

Sanz, M.E., Wright, V.P., 1994. Modelo altemativo para el desarrollo de calcretas: un ejemplo del Plio-Cuatemario de la Cuenca de Madrid. Geogaceta 16, 116-119.

Silva, P.G., 1994. Evolución geodinánica de la Depresión del Guadalentín desde el Mioceno superior hasta la actualidad: Neotectónica y Geomorfología. PhD Thesis UCM, Marrid, 642 pp. unpublished.

Silva, P.G., Harvey, A.M., Zazo, C., Goy, J.L., 1992. Geomorphology, depositional style and morphometric relationships of Quatemary alluvial fans in the Guadalentín Deppresion (Murcia, SE Spain). Z. F. Geomorph. 36 (3), 661-673.

Silva, P.G., Goy, J.L., Somoza, L., Zazo, C., Bardají, T., 1993. Landscape response to strike-slip faulting linked to collisional settings: Quaternary tectonics and basin formation in the Eastem Betics (SE Spain). Tectonophysics 224, 289-303.

Silva, P.G., Goy, J.L., Zazo, C., Bardají, T., 1996. Recent drainage evolution in the Guadalentín Depression (Murcia, SE Spain). Geogaceta 20 (5), 1100-1103

Somoza, L., Zazo, C., Goy, J.L., Mörner, N.A., 1989. Estudio geomorfológico de secuencias de abanicos aluviales cuater- 
narios (Alicante-Murcia, España). Cuaternario Geomorfol. 3, 73-82.

Tandon, S.K., Friend, P.F., 1989. Near-surface shrinkage and carbonate replacement processes, Arran Comstone Formation, Scotland. Sedimentology 36, 1113-1126.

Verrecchia, E.P., 1987. Le contexte morpho-dynamique des croûtes calcaires : apport des analysis séquentielles à l'escale microscopique. Zeitschrift Geomorphol. 31, 179-193.

Verrecchia, E.P., Ribier, J., Patillon, M., Rolko, K.E., 1991. Stromatolitic origin of desert laminar limecrusts. Naturwissenschaften 78, 505-507.

Verrecchia, E.P., Dumont, J., Verrecchia, K.E., 1993. Role of calcium oxalate biomineralization by fungi in the formation of calcretes: a case study from Nazareth, Israel. J. Sediment. Petrol. 63, 1000-1006.

Verrecchia, E.P., Freytet, P., Verrecchia, K.E., Dumont, J., 1995. Spherulites in calcrete laminar crusts: biogenic $\mathrm{CaC}_{3}$ precipitation as a major contributor to crust formation. J. Sediment. Petrol. A 65, 690-700.

Vogt, T., 1984. Problèmes de genèse des croûtes calcaires quaternaires. Bull. Centres Rech. Explor.-Prod. Elf-Aquitaine 8, 209-221.

Watts, N.L., 1980. Quatemary pedogenetic calcrete from the Kalahari, mineralogy, genesis and diagenesis. Sedimentology $27,661-687$.
Wells, N.A., 1983. Carbonate deposition, physical linmology and environmentally controlle chert formation in PaleoceneEocene Lake Flagstaff, Central Utah. Sediment. Geol. 35, 263-296.

Wright, V.P., 1986. The role of fungal biomineralization in the formation of Early Carboniferous soil fabrics. Sedimentology $33,831-838$.

Wright, V.P., 1991. Calcretes: an introduction. In: Wright, V.P., Tucker, M.E. (Eds.), Calcretes. Reprint Series, Vol. 2. Int. Ass. Sediment., 1-22.

Wright, V.P., Platt, N.H., Marriot, S.B., Beck, V.H., 1995. A classification of rhizogenic (root-formed) calcretes, with examples from the Upper Jurassic-Lower Cretaceous of Spain and Upper Cretaceous of southem France. Sediment. Geol. 100, 143-158.

Wright, V.P., Alonso-Zarza, A.M., 1990. Pedostratigraphic models for alluvial fan deposits: a tool for interpreting ancient sequences. J. Geol. Soc. London 147, 8-10.

Wright, V.P., Peeters, C., 1989. Origins of some Early Carboniferous calcrete fabrics revealed by cathodoluminescence: implications for interpreting the sites of calcrete formation. Sediment. Geol. 65, 345-353. 